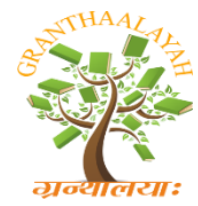

INTERNATIONAL JOURNAL OF RESEARCH GRANTHAALAYAH A knowledge Repository

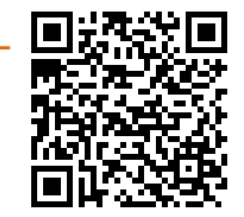

Management

\title{
LEADERSHIP BEHAVIOUR OF B.Ed. TRAINEES
}

\author{
Dr. J. Kiruba *1 \\ ${ }^{* 1}$ Principal, Bethlahem College of Education, Karungal, 629157, India
}

DOI: https://doi.org/10.29121/granthaalayah.v4.i12SE.2016.2481

\begin{abstract}
Leadership is an important aspect of managing people. It is the art of dealing with and influencing people so that they will try hard happily and actively toward the achievement of group or organizational goals. The leaders understand what makes their followers to get motivated and how well these motivations operate. This understanding will reflect in their leadership behaviour. Preparing young people for leadership responsibility begins at home with an enriched environment that offers opportunities for children to acquire broad interests, selfesteem and the insights and skills that characterize leaders. Parents can provide their children with support and encouragement as they participate in a wide variety of home and community activities. The aim of the present study is to find out the level of leadership behaviour of B.Ed. trainees. The investigator has used the leadership behavior inventory as tool. The sample consists of 300 B.Ed. trainees from six B.Ed. Colleges in Kanyakumari District. Stratified random sampling technique has been used for collecting the data. The major finding reveals that there is significant difference between rural and urban B.Ed trainees in their leadership behaviour.
\end{abstract}

Keywords: Leadership; Behaviour; Trainees.

Cite This Article: Dr. J. Kiruba. (2016). "LEADERSHIP BEHAVIOUR OF B.Ed. TRAINEES." International Journal of Research - Granthaalayah, 4(12)SE, 68-72. https://doi.org/10.29121/granthaalayah.v4.i12SE.2016.2481.

\section{Introduction}

\section{Rationale for the Study}

Education is a noble calling that entails both challenges and responsibilities. One of the main aims of education is to produce good leaders. Strong accountable leadership is always a hallmark of successful individuals. It is a known fact that, the development of a society depends on its directive leaders. A leader is one who guides, organizes, directs and co-ordinates the society. Leadership is the ability to persuade others to seek defined objectives enthusiastically. 
Adequacy of leadership is very material for the students of higher education. Because, all B.Ed. trainees need leadership qualities and the related skills are needed virtually in all areas. It is the human factor, which binds a group together and motivates it towards the goals. To be effective leaders, they must bring the core principles of quality leadership to their decision making and interaction with others. The emotional component of leadership requires the ability to perceive emotions, facilitate emotions in thought and understand and manage emotions. Leaders possessing these abilities are considered emotionally intelligence. Because intelligently governed emotion play a significant role in directing and shaping one's leadership behaviour and personality. The B.Ed. trainees with ample leadership behaviour can lead anything successfully. The present scenario necessitates the effective intelligent leaders. Being very much inspired by the above discussion, the investigator has prepared her mind to study the leadership behaviour of B.Ed. trainees.

\section{Objectives}

1) To find out whether there is any significant difference between male and female B.Ed. trainees in their leadership behaviour.

2) To find out whether there is any significant difference between rural and urban B.Ed. trainees in their leadership behavior.

3) To find out whether there is any significant difference between undergraduate and post graduate B.Ed. trainees in their leadership behaviour.

4) To find out whether there is any significant difference among Tamil, English, Maths, Physical Science, Bio Science and History B.Ed. trainees in their leadership behaviour.

\section{Methodology}

The investigator has adopted survey method of research to study the leadership behaviour of B.Ed. trainees.

\section{Sample}

The population of the present study consists of the B.Ed. trainees of six B.Ed. colleges in Kanyakumari District. A sum of 300 B.Ed. trainees is selected as the sample by stratified random sampling.

\section{Tools Used in the Present Study}

The investigator has used the leadership behaviour inventory to find out the leadership behaviour of the B.Ed. trainees.

\section{Analysis of Data}

To interpret the raw scores meaningfully, the data are analyzed by using mean, standard deviation and ' $\mathrm{t}$ '- test. 


\section{Null Hypothesis 1}

There is no significant difference between male and female B.Ed. trainees in their leadership behaviour.

Table 1: Difference between Male and Female B.Ed. Trainees in their Leadership Behaviour

\begin{tabular}{|c|c|c|c|c|c|c|}
\hline \multirow{3}{*}{$\begin{array}{l}\text { Leadership } \\
\text { behaviour }\end{array}$} & \multicolumn{2}{|c|}{ Male $(\mathrm{N}=126)$} & \multicolumn{2}{|c|}{ Female $(N=174)$} & \multirow{2}{*}{$\begin{array}{l}\text { Calculated } \\
\text { Value of ' } t \text { ' }\end{array}$} & \multirow{2}{*}{$\begin{array}{l}\text { Remarks at } \\
5 \% \text { level }\end{array}$} \\
\hline & Mean & S.D & Mean & S.D & & \\
\hline & 86.77 & 15.28 & 88.56 & 14.94 & 1.02 & NS \\
\hline
\end{tabular}

From the above table it is clear that, there is no significant difference between male and female B.Ed. trainees in their leadership behaviour, as the calculated ' $t$ ' value 1.02 is less than the table value 1.96 , at $5 \%$ level of significance. Hence the Null hypothesis is accepted.

\section{Null Hypothesis 2}

There is no significant difference between rural and urban B.Ed. trainees in their leadership behaviour.

Table 2: Difference between Rural and Urban B.Ed. Trainees in their Leadership Behaviour

\begin{tabular}{|l|l|l|l|l|l|l|}
\hline \multirow{3}{*}{$\begin{array}{l}\text { Leadership } \\
\text { behaviour }\end{array}$} & Rural (N=150) & \multicolumn{2}{|l|}{ Urban (N=150) } & $\begin{array}{l}\text { Calculated } \\
\text { Value of 't' }\end{array}$ & $\begin{array}{l}\text { Remarks at } \\
\text { 5\% level }\end{array}$ \\
\cline { 2 - 7 } & 89.67 & 13.44 & 85.95 & 16.41 & 2.15 & S \\
\hline
\end{tabular}

(At $5 \%$ level of significance, the table value of ' $t$ ' is 1.96 )

From the above table, it is inferred that, there is significant difference between rural and urban B.Ed. trainees in their leadership behaviour, as the calculated' $t$ ' value 2.15 is greater than the table value 1.96 , at $5 \%$ level of significance. Hence the Null hypothesis is rejected.

\section{Null Hypothesis 3}

There is no significant difference between undergraduate and postgraduate B.Ed. trainees in their leadership behaviour.

Table 3: Difference between Undergraduate and Post Graduate B.Ed. Trainees in their Leadership Behaviour

\begin{tabular}{|l|l|l|l|l|l|l|}
\hline \multirow{2}{*}{$\begin{array}{l}\text { Leadership } \\
\text { behaviour }\end{array}$} & \multicolumn{2}{|l|}{ UG (N=211) } & \multicolumn{2}{l|}{ PG (N=89) } & Calculated & $\begin{array}{l}\text { Remarks at } \\
\text { Value of ' } \mathbf{~} \text { ' }\end{array}$ \\
\cline { 2 - 7 } & Mean & S.D & Mean & S.D & NS \\
\cline { 2 - 7 } & 87.74 & 14.90 & 87.98 & 15.62 & 0.13 & \\
\hline
\end{tabular}

(At $5 \%$ level of significance, the table value of ' $t$ ' is 1.96 ) 
From the above table it is clear that, there is no significant difference between undergraduate and post graduate B.Ed. trainees in their leadership behaviour, as the calculated ' $t$ ' value 0.13 is less than the table value 1.96, at 5\% level of significance. Hence the Null hypothesis is accepted.

\section{Null Hypothesis 4}

There is no significant difference among English, Tamil, Maths, History, Physical Science and Biological Science B.Ed. trainees in their Leadership behaviour.

Table 4: Difference among English, Tamil, Maths, History, Physical Science and Biological Science B.Ed. Trainees in their Leadership Behaviour

\begin{tabular}{|l|l|l|l|l|l|}
\hline \multirow{2}{*}{$\begin{array}{l}\text { Leadership } \\
\text { behaviour }\end{array}$} & $\begin{array}{l}\text { Source of } \\
\text { Variation }\end{array}$ & $\begin{array}{l}\text { Sum of } \\
\text { square }\end{array}$ & $\begin{array}{l}\text { F- } \\
\text { Value }\end{array}$ & Table Value & $\begin{array}{l}\text { Remarks at } \\
\text { 5\% level }\end{array}$ \\
\cline { 2 - 5 } & $\begin{array}{l}\text { Between } \\
\text { Within }\end{array}$ & $\begin{array}{l}815.64 \\
67260.54\end{array}$ & 0.71 & 2.25 & NS \\
\hline
\end{tabular}

(At $5 \%$ level of significance, the table value of ' $\mathrm{F}$ ' is 2.25 )

From the above table it is clear that, there is no significant difference among English, Tamil, Maths, History, Physical Science and Biological Science B.Ed. Trainees in their Leadership behaviour, as the calculated ' $F$ ' value 0.71 is less than the table value 2.25 at $5 \%$ level of significance. Hence the Null Hypothesis is accepted.

\section{Findings}

1) There is no significant difference between male and female B.Ed. trainees in their leadership behaviour.

2) There is significant difference between rural and urban B.Ed. trainees in their leadership behaviour.

3) There is no significant difference between under graduate and post graduate B.Ed. trainees in their leadership behaviour.

4) There is no significant difference among English, Tamil, History, Physical science and Biological Science B.Ed. trainees in their leadership behaviour.

\section{Discussion}

The leadership potential of B.Ed. trainees can be enhanced by encouraging them to plan, initiate and complete a variety of self-evaluated individual projects. Provide opportunities for decision making at an early age which helps them to foster critical reasoning skills necessary to be an effective leader. Outreach programmes namely NSS, Scout and Guides etc., may be conducted to develop leadership qualities among B.Ed. trainees. Necessary guidance and counseling may be given to the B.Ed. trainees, to develop leadership qualities.

Some people hold the view that leaders are born and not made. This view point is not acceptable to the modern man in a democratic age. If ample and equal opportunities are provided to all, 
everyone who has the aptitude will make use of it and become leaders. So, leaders are not born but made. Leadership development is not an event. It is a process of participating in respectful conversations where the leader recognizes his feelings and those of others in building safe and trusting relationships. Leadership development is self-development. The teacher training colleges should provide enough opportunities to B.Ed. trainees to plan and organize various functions and festivals like annual day, sports day, science exhibition, quiz programmes, cultural programmes, youth festivals, releasing the annual magazine, etc. Through such activities alone one could foster the leadership qualities like planning meticulously any programme, mobilising the requisite resources for successfully carrying out the programme, unifying and integrating the men and materials in any given system and the flexibility and courage to incorporate necessary changes in the action plan. Even in teaching, adopting techniques like discussions, debates, assignments and quiz programmes will be of much use in promoting mutual dependence and self-confidence among B.Ed. trainees. Through proper planning and functioning, educational institutions can help in producing the leaders of the next generation.

\section{References}

[1] Abel Anyieni \& Martin Onsiro Ronald (2011). Leadership in Indian organization. Education Today, 02(02), 97-103.

[2] Ajay kumar Attri, S. (2010). Leadership styles among distance learners. International Journal of Education and Research, 43(03).

[3] Carrison, (1979). Psychology of adolescents. William Marrow and Company.

[4] Dollard, J. and Miller, N.E. (1950). Personality and psychotherapy: An analysis in terms of language, thinking and culture. New York: McGraw Hill.

[5] Golden, S. A. R. (2011). Problems and Prospectus of Distance Education. Quality Enhancement In Distance Education For Life Long Learning, 1(1), 343-344.

[6] Golden, S. A. R. (2011). Strategy For Success Of Human Beings:-Time Management. Department Of BBA, St. Joseph's College, Trichy, 388, 390.

[7] Golden, S. A. R. (2016). RURAL STUDENTS' ATTITUDE TOWARDS ENGLISH AS MEDIUM OF INSTRUCTION IN HIGHER EDUCATION - AN ANALYSIS. International Journal of Research, 3(Special Issue - 16), 1-10.

[8] Mangal, S.K. (2008). Advanced educational psychology. Ludhiana: Tandon Publications.

[9] Panda, B.N. (1999). Advanced educational psychology. New Delhi: Discovery Publishing House.

[10] Pandey, V.C. (2001). Education and globalization. Delhi: Kalpaz publication.

[11] Portia, R. (2012). Leadership potential of student teachers in Tiruchirapalli District. Education Plus, 1(2), 16-20.

[12] Regi, S. B., \& Golden, S. A. R. (2014). A Study On Attitude Of Employee Towards Working Environment With Special Reference To RR Pvt Ltd. Review Of Research, 2 (2), 1, 5.

[13] Santhosh Gupta. (1999). Research Methodology and statistical techniques. New Delhi: Deep and Deep publications.

[14] Sharma (2005). Leadership behaviour perception of principals, teachers and guardians. Journal of All India Association, 17(6), 21-23.

[15] Usha Rao. (2006). Advanced educational psychology. Hyderabad: Neelkamal Publications. 